\title{
Isotopic change throughout the life history of a Lake Malawi cichlid fish
}

\author{
M. J. Genner*†, S. J. Hawkinst\& and G. F. Turner \\ * Institute for Biodiversity and Ecosystem Dynamics, University of Amsterdam, P. O. \\ Box 94766, 1090 GT Amsterdam, The Netherlands, $\$$ Marine Biological Association of \\ the U.K. Citadel Hill, Plymouth PL1 2PB, U.K., §School of Biological Sciences, \\ University of Southampton, Southampton SO16 7 PX, U.K. and Department of \\ Biological Sciences, University of Hull, Hull HU6 7RX, U.K.
}

(Received 25 July 2002, Accepted 24 February 2003)

\begin{abstract}
Clear changes in body size-isotope (carbon and nitrogen) trajectories of Pseudotropheus callainos, a cichlid belonging to the endemic haplochromine species radiation in Lake Malawi, were found that corresponded with an ontogenetic dietary shift from predominantly planktonic to benthic food sources. The results indicated that dietary switching was a proximate cause of isotopic change over the life history of this species and confirmed the value of stable isotope signatures for inferring diet. The data also illustrated that possible variability of signatures over the life history of a species should be considered when using stable isotope ratios to investigate fine-scale ecological differentiation among taxa.

(C) 2003 The Fisheries Society of the British Isles
\end{abstract}

Key words: cichlid fish; diet; ecology; Lake Malawi; stable isotopes.

\section{INTRODUCTION}

Dietary relationships between predators and prey have long been studied using stomach content analysis, direct observations or collection of prey remains. These techniques enable monitoring of short-term dietary intake, but, unless samples are regularly collected, are unable to indicate long-term feeding strategies and can suffer when some species eat only infrequently (Beaudoin et al., 1999), or rapidly digest soft-bodied prey (Hobson et al., 1994). An alternative approach is to use naturally occurring stable isotope ratios of tissue as dietary tracers (Peterson \& Fry, 1987). Isotopic ratios of carbon $\left({ }^{13} \mathrm{C}:{ }^{12} \mathrm{C}\right.$, expressed as $\left.\delta^{13} \mathrm{C}\right)$ and nitrogen $\left({ }^{15} \mathrm{~N}:{ }^{14} \mathrm{~N}\right.$, expressed as $\left.\delta^{15} \mathrm{~N}\right)$ are commonly used. There is little enrichment $(0-1 \%$ o $)$ of ${ }^{13} \mathrm{C}$ in body tissue of a predator relative to its prey; thus $\delta^{13} \mathrm{C}$ ratios generally reflect isotopic composition of the diet (DeNiro \& Epstein, 1978). In contrast, more substantial enrichment $\left(3-4 \%\right.$ o of ${ }^{15} \mathrm{~N}$ in body tissue takes place in a stepwise manner during each stage in the food chain, and so $\delta^{15} \mathrm{~N}$ ratios provide an estimate of trophic level (Kelly, 2000). Isotopic

†Author to whom correspondence should be addressed. Tel.: +31 205257235 ; fax: +31205255402 ; email: genner@science.uva.nl 
signatures have been successfully used as indicators of trophic relationships within food webs (Hobson et al., 1994; Harvey \& Kitchell, 2000) and for examining interspecific dietary differentiation (Fry et al., 1999). They have also proven useful for identifying migration routes and natural origins of individuals (Hobson, 1999).

It is recognized that stable isotopes accumulate in tissues (Fry \& Arnold, 1982) and isotopic turnover rates vary with the metabolic rates of the tissues analysed (Hobson \& Clark, 1992; Pinnegar \& Polunin, 1999). Nevertheless, stable isotope ratios within any given tissue are commonly viewed as static or rapidly reaching the isotopic composition of the primary food source in an asymptotic manner with increasing body size or age. Exceptions to this pattern are generally attributed to the influence of dietary or habitat switches to food or environments with intrinsically different isotopic signatures or major metabolic changes associated with starvation (Beaudoin et al., 1999; Doucett et al., 1999a, b; Fry et al., 1999; Harvey \& Kitchell, 2000; Griffin \& Valiela, 2001). Overall, it appears that a comprehensive understanding of the life history of taxa is critical for interpreting isotopic change. The present study focused on a non-migratory species of cichlid fish endemic to rocky habitats of Lake Malawi. The primary aims were to determine: (1) if stomach contents indicate dietary changes during the life history of the species and (2) if and how the observed changes were reflected in carbon and nitrogen stable isotope signatures.

\section{MATERIALS AND METHODS}

\section{STUDY SPECIES}

The cobalt zebra cichlid Pseudotropheus callainos Stauffer \& Hert is endemic to Lake Malawi. Adult males hold territories over rocky habitats that are used as both foraging and breeding sites (Ribbink et al., 1983). The smaller adult females are polygamous mouthbrooders, releasing juveniles of $c .13 \mathrm{~mm}$ total length $\left(L_{\mathrm{T}}\right)$ that take refuge in crevices until they reach $c .55 \mathrm{~mm}$ and become non-territorial 'floating' individuals. Males mature and adopt territories at $c .85 \mathrm{~mm}$. Females reach maturity at $c .70 \mathrm{~mm}$ and, while they appear to adopt home ranges (M.E. Knight, unpubl. data), they do not aggressively defend territories. Stretches of sand and deep water severely limit dispersal between rocky habitat patches (van Oppen et al., 1997).

\section{SAMPLE COLLECTION}

Sampling was conducted at rocky littoral habitats at Nkhata Bay $\left(11^{\circ} 36^{\prime} \mathrm{S} ; 34^{\circ} 18^{\prime} \mathrm{E}\right)$, Malawi. Five ontogenetic or sex categories of $P$. callainos were selected: juveniles $\left(\leq 55 \mathrm{~mm} L_{\mathrm{T}}\right)$, sub-adult males $(55-85 \mathrm{~mm})$, sub-adult females $(55-70 \mathrm{~mm})$, adult males $\left(>85.1 \mathrm{~mm} L_{\mathrm{T}}\right)$ and adult females $(>70.1 \mathrm{~mm})$. Fish were collected using SCUBA. For juveniles, $1 \mathrm{~m}^{2}$ sheets of mosquito mesh were placed on a rocky substratum, small stones piled on top and left for 1 week. On return, the edges of the mesh were drawn tight, stones removed and resultant bags containing juveniles lifted to the surface. Adults and sub-adults were caught in a monofilament $10 \times 2 \mathrm{~m}$ block net $(20 \mathrm{~mm}$ stretched mesh), placed in a keepnet and lifted to the surface. Fourteen individuals of each ontogenetic or sex category were collected and killed as soon as possible by immersion in 2-phenoxyethanol (2-PE) anaesthetic. Plankton were collected in a $50 \mu \mathrm{m}$ mesh phytoplankton net from hauls at $10 \mathrm{~m}$ depth from inshore Nkhata Bay. It was not possible to separate the phytoplankton and zooplankton fractions. Epilithic algae were collected from small rocks. Samples were obtained between 11 June and 1 July 1997. 


\section{STOMACH CONTENT ANALYSIS}

Stomach contents were removed and preserved in formalin. Two individuals, one subadult male and one sub-adult female, had empty stomachs. Dietary constituents were identified under $\times 100$ to $\times 400$ magnification and classified into 20 categories: Anabaena sp., Botrycoccus sp., Calothrix sp., Microcystis sp., Oscillatoria sp., Cladophora sp., Mougoetia sp., Staurastrum sp., Cosmarium sp., Aulacoseira sp., Cymbella sp., Cymatopleura sp., Gomphonema sp., Navicula sp., Pinnularia sp., centric diatoms, zooplankton, silt, detritus and fish scales. Zooplankton remains in the stomachs were usually masticated and it was impossible to identify remains to species or genus levels. Volumetric proportions of food items within each stomach were calculated from an average of eight sub-samples. Constituents within each sub-sample were quantified using the following technique. The dietary component with the highest volume was allocated 16 points. Subsequently every other dietary component was awarded $16,8,4,2,1$ or 0 points depending upon volume relative to the component with the highest volume. Percentage volumes within each sub-sample were calculated as: \%o volume of component $\alpha=$ (number of points allocated to component $\alpha$ )(total points allocated to subsample $\times 100)^{-1}$. This technique enabled a comparatively rapid assessment of stomach content and overcame problems of measuring volumes of microscopic organisms such as diatoms and filamentous algae that were frequently clumped. The computer package PRIMER 5 (PRIMER-E Ltd, Plymouth, U.K.) was used to analyse stomach content data using the following techniques. A similarity matrix of diet of the 68 individuals was constructed using the Bray-Curtis similarity coefficient (Bray \& Curtis, 1957). Multidimensional scaling (MDS) using this matrix enabled a two dimensional illustration of dietary similarity among individuals to be constructed. To test for differences in stomach contents among the five ontogenetic or sex categories, non-parametric one-way ANOSIM (analysis of similarities) was employed on the similarity matrix. ANOSIM is a non-parametric test analogous to ANOVA. The test involves calculation of global test statistic $(R)$ by contrasting the variance in similarity within groups to that between groups. The significance of this test statistic is then tested using a permutation procedure (Clarke \& Warwick, 1994).

\section{STABLE ISOTOPE ANALYSIS}

For fish $>55 \mathrm{~mm} L_{\mathrm{T}}$, a fillet of dorsal white muscle was taken and for smaller fish whole eviscerated individuals were used. Tissues differ in their isotopic composition (Pinnegar \& Polunin, 1999). Thus inclusion of a wider variety of tissues in juveniles may have influenced results. Given that different tissues tend to follow similar, or at least non-contrasting patterns of isotopic change (Doucett et al., 1999a), this should not have influenced the resulting trends. It is also possible that absorbed anaesthetic (2-PE), an organic compound, may have influenced the carbon isotope signatures in this study. Nevertheless it was assumed that the risk of 2-PE affecting isotopic signatures within muscle tissue during the short exposure time would be negligible for two reasons: (1) the mass of additional carbon absorbed in tissue originating from 2-PE is likely to be negligible to the carbon already present within the tissue. Thus the total mass of carbon isotopes contributing to the results of this study by 2-PE will be equivalently negligible; (2) 2-PE is not actively accumulated in muscle tissue. Rather after being absorbed through the gills and entering the systemic circulation system, the compound and resultant metabolites accumulate in the liver, but are rapidly released back into the circulation system and excreted via the gills (Weyl et al., 1996).

All samples were sun-dried to constant mass and stored independently with desiccant (silica gel; 4-7 mesh) before being ground to a fine homogeneous powder using a pestle and mortar. Powdered samples weighing either $1.0 \pm 0.1 \mathrm{mg}$ (range) for fish or $3.0 \pm 0.1 \mathrm{mg}$ for epilithic algae and plankton were placed into tin capsules that were immediately sealed. $\delta^{15} \mathrm{~N}$ and $\delta^{13} \mathrm{C}$ were determined using continuous flow isotope ratio mass spectrometry (Preston, 1992). Analyses were conducted at the University of Newcastle, U.K., using a PDZ-Europa (Crewe, U.K.) ANCA 20/20 isotope ratio mass 
spectrometer. Samples were analysed in a series of four runs of up to 50 samples. A cod Gadus morhua L. reference sample (for instrument drift correction) and a cod control sample with known isotopic constituents (for system calibration) were analysed at the start of each run and subsequently every fifth cichlid or potential food sample. $\delta^{13} \mathrm{C}$ and $\delta^{15} \mathrm{~N}$ were measured as parts per thousand differences (\%o) between the isotope ratio of the sample and that of standards using the formula:

$$
\delta X=10^{3}\left[\left(R_{\text {sample }}\right)\left(R_{\text {standard }}\right)^{-1}\right]
$$

where $X={ }^{15} \mathrm{~N}$ or ${ }^{13} \mathrm{C}$ for $R={ }^{15} \mathrm{~N}:{ }^{14} \mathrm{~N}$ or ${ }^{13} \mathrm{C}:{ }^{12} \mathrm{C}$, respectively. Following International Atomic Energy Agency standards, carbon isotopic controls were calibrated relative to Peedee Belemnite (PDB) limestone and nitrogen measurements were calibrated to atmospheric nitrogen. Standard deviation from the means of control samples were: run 1, $\delta^{13} \mathrm{C} 0.02 \%$ and $\delta^{15} \mathrm{~N} 0.06 \%$; run $2, \delta^{13} \mathrm{C} 0.04 \%$ and $\delta^{15} \mathrm{~N} 0.03 \%$; run $3, \delta^{13} \mathrm{C} 0.04 \%$ \% and $\delta^{15} \mathrm{~N} 0.06 \%$.

\section{RESULTS}

Significant differences were found in stomach contents between the ontogenetic or sex categories (one-way ANOSIM, 5000 permutations, global test statistic $R=0.375, P<0 \cdot 001)$. Post-hoc ANOSIM comparisons revealed significant differences between stomach contents of juveniles and all other ontogenetic or sex categories (Table I). Juveniles were found to have a mainly phytoplanktonbased diet while sub-adults and adults consumed a higher proportion of epilithic algae and zooplankton (Fig. 1). The analysis also revealed non-significant differences between sub-adult males and females and between sub-adults and adults of each sex; yet significant differences between the sexes when adult (Table I). In general, the sex and maturity of sub-adult and adult individuals could not be classified on the basis of diet (Fig. 2).

TableI. Post-hoc pair-wise statistical comparisons of mean isotopic composition (Tukey's HSD test) and stomach contents (one-way ANOSIM) among the five ontogenetic or sex categories. Note that in these analyses no corrections have been made for total length

\begin{tabular}{|c|c|c|c|c|c|}
\hline Data & $\begin{array}{c}\text { Sex or ontogenetic } \\
\text { stage }\end{array}$ & $\begin{array}{l}\text { Adult } \\
\text { males }\end{array}$ & $\begin{array}{c}\text { Adult } \\
\text { females }\end{array}$ & $\begin{array}{l}\text { Sub-adult } \\
\text { males }\end{array}$ & $\begin{array}{l}\text { Sub-adult } \\
\text { females }\end{array}$ \\
\hline \multirow[t]{4}{*}{$\delta^{13} \mathrm{C}$} & Adult females & $P<0.001$ & & & \\
\hline & Sub-adult males & $P<0.001$ & $P<0.001$ & & \\
\hline & Sub-adult females & $P<0.001$ & $P<0.001$ & NS & \\
\hline & Juveniles & $P<0.001$ & $P<0.001$ & NS & NS \\
\hline \multirow[t]{4}{*}{$\delta^{15} \mathrm{~N}$} & Adult females & $P<0.01$ & & & \\
\hline & Sub-adult males & $P<0.001$ & NS & & \\
\hline & Sub-adult females & $P<0.001$ & $P<0.05$ & NS & \\
\hline & Juveniles & NS & $P<0.01$ & $P<0.001$ & $P<0.001$ \\
\hline \multirow{4}{*}{$\begin{array}{l}\text { Stomach } \\
\text { contents }\end{array}$} & Adult females & $P<0.001$ & & & \\
\hline & Sub-adult males & NS & NS & & \\
\hline & Sub-adult females & NS & NS & NS & \\
\hline & Juveniles & $P<0.001$ & $P<0.001$ & $P<0.001$ & $P<0.001$ \\
\hline
\end{tabular}




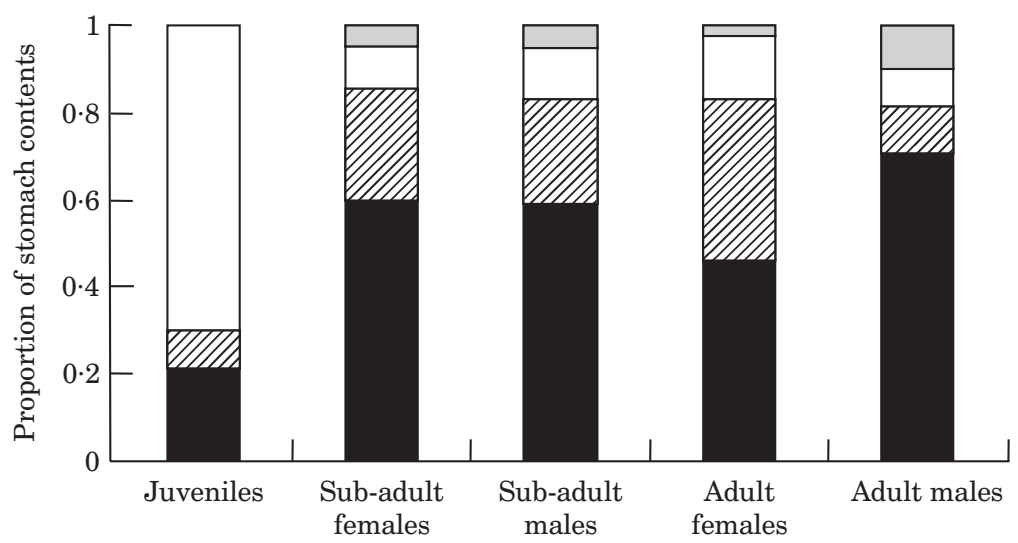

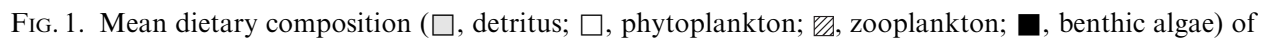
Pseudotropheus callainos ontogenetic or sex categories. For each category $n=14$, except sub-adult males and females, both $n=13$.

Benthic algal samples had higher $\delta^{13} \mathrm{C}$ (mean, -7.9\%) and lower $\delta^{15} \mathrm{~N}$ (mean, $-0.8 \%$ ) than plankton samples (mean, $\delta^{13} \mathrm{C}-21.6 \%$; mean, $\delta^{15} \mathrm{~N} 2.4 \%$; Fig. 3). The plankton signature was likely to be a consequence of both phytoplankton and zooplankton being present within the sample. Tissue samples of $P$. callainos had comparatively higher $\delta^{15} \mathrm{~N}$ than both plankton and benthic algae (mean, $5.9 \%$ ), while $\delta^{13} \mathrm{C}$ signatures lay between plankton and benthic algae (mean, $-17.1 \%$; Fig. 3). Pseudotropheus callainos was enriched in ${ }^{15} \mathrm{~N}$ over major food sources by $c .3-6 \%$. Intraspecific variation was smaller in $\delta^{15} \mathrm{~N}$ (range, 1.3\%o) than $\delta^{13} \mathrm{C}$ (range, 9.7\%). The global test statistic showed that mean $\delta^{13} \mathrm{C}$ and

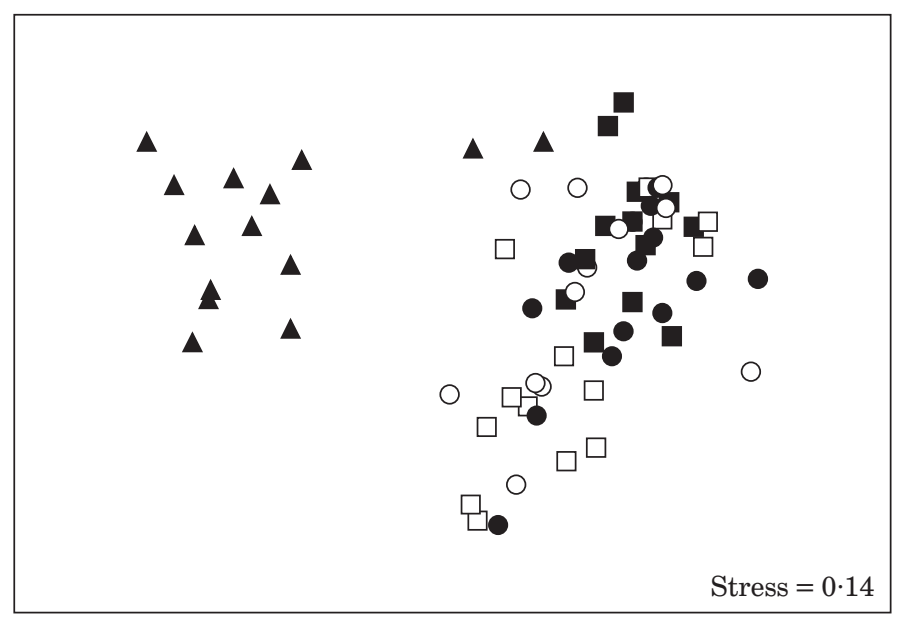

FIG. 2. Multidimensional scaling (MDS) ordination plot of dietary composition of the five ontogenetic or sex categories [adult males ( $\square$ ), adult females $(\square)$, sub-adult males $(\bullet)$, sub-adult females (O) and juveniles ( $\mathbf{\Delta})$ ] of Pseudotropheus callainos; closer points indicate individuals with more similar stomach contents; scaling uses raw data that includes all 20 categories of dietary components quantified. A stress value of $0 \cdot 14$ indicates a good two-dimensional representation of the data (Clarke \& Warwick, 1994). 


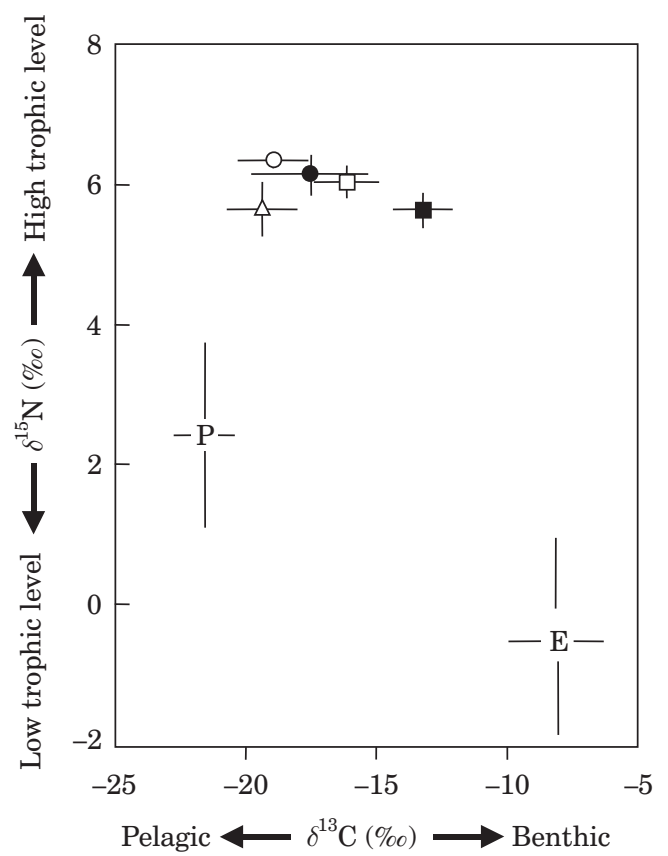

FIG. 3. Mean \pm S.D. isotopic composition of five ontogenetic or sex categories of Pseudotropheus callainos

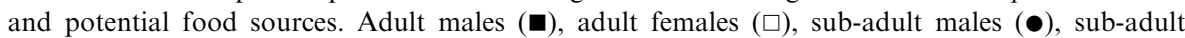
females (O), juveniles $(\Delta)$, plankton $(\mathrm{P})$ and epilithic algae (E). For each ontogenetic or sex stage $n=14$, plankton $n=4$, epilithic algae $n=16$. Labels next to arrows indicate food sources commonly associated with isotopic signatures in lacustrine systems (Bootsma et al., 1996).

$\delta^{15} \mathrm{~N}$ of the five ontogenetic or sex categories differed significantly (Systat GLM, Wilk's $\lambda=0.080, F_{8,128}=40.679, P<0.001$, Fig. 3, Table I). Post-hoc analyses showed that in most cases either $\delta^{15} \mathrm{~N}$ or $\delta^{13} \mathrm{C}$ showed significant among-group differences. The only among-group comparison where nonsignificant differences were present in both $\delta^{15} \mathrm{~N}$ and $\delta^{13} \mathrm{C}$ was in the comparison between sub-adult males and females. Plotting isotopic values with $L_{\mathrm{T}}$ revealed a clear change with body size (Fig. 4). Juveniles had a significant positive association of $\delta^{15} \mathrm{~N}$ with increasing $L_{\mathrm{T}}$ (slope, $0.06 ; F_{1,12}=32.32, P<0.001$ ), and a negative association $\delta^{13} \mathrm{C}$ of with increasing $L_{\mathrm{T}}$ (slope, -0.22 ; $\left.F_{1,12}=58.10, P<0 \cdot 001\right)$. When adult and sub-adults were grouped by sex, both sexes had negative associations of $\delta^{15} \mathrm{~N}$ with increasing $L_{\mathrm{T}}$ (males: slope, $-0.02 ; F_{1,23}=42.46, P<0.001$ ) (females: slope, $-0.02 ; F_{1,23}=17 \cdot 19$, $P<0 \cdot 001$ ), and positive associations of $\delta^{13} \mathrm{C}$ with greater $L_{\mathrm{T}}$ (males: slope, $0.19 ; F_{1,23}=171.47, P<0.001$ ) (females: slope, $0.22 ; F_{1,23}=68.06 ; P<0.001$ ). When $L_{\mathrm{T}}$ was included as a covariate in ANCOVA, no significant differences were present between the sexes $\left(\delta^{15} \mathrm{~N}, P=0 \cdot 30 ; \delta^{13} \mathrm{C}, P=0 \cdot 41\right)$.

\section{DISCUSSION}

The analyses revealed considerable change in the isotopic signatures of the study species with increasing body size. The tissues of juvenile $P$. callainos 

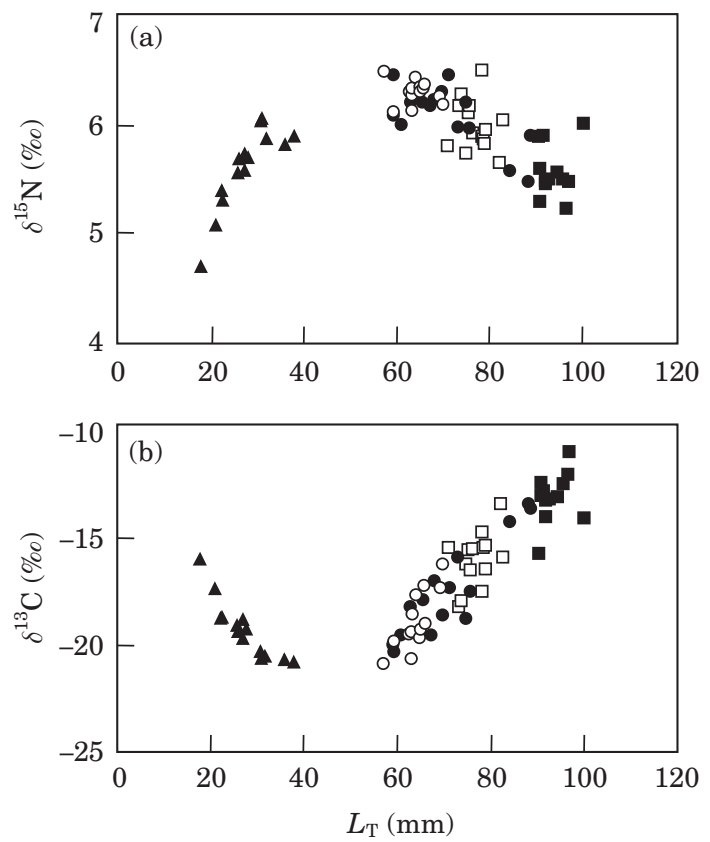

FIg. 4. $\delta^{15} \mathrm{~N}$ and $\delta^{13} \mathrm{C}$ of individuals plotted against total length $\left(L_{\mathrm{T}}\right)$ of Pseudotropheus callainos individuals. [Adult males $(\boldsymbol{\square})$, adult females $(\square)$, sub-adult males $(\bullet)$, sub-adult females $(O)$ and juveniles $(\mathbf{\Delta})]$.

showed lower $\delta^{13} \mathrm{C}$ and higher $\delta^{15} \mathrm{~N}$ with increasing body size, while those of sub-adult and adults of both sexes showed higher $\delta^{13} \mathrm{C}$ and lower $\delta^{15} \mathrm{~N}$ with increasing $L_{\mathrm{T}}$. Stomach content analysis showed that isotopic change corresponded with a switch from a predominantly planktivorous feeding mode in juveniles to a more benthic-feeding mode in sub-adults and adults of both sexes. Given increased planktivory results in enrichment of ${ }^{15} \mathrm{~N}$ and depletion of ${ }^{13} \mathrm{C}$, and increased herbivory results in depletion of ${ }^{15} \mathrm{~N}$ and enrichment of ${ }^{13} \mathrm{C}$ (Bootsma et al., 1996), the results are compatible with diet being a proximate cause of the trajectory of isotopic shifts. Thus, this study confirms that isotopic signatures are useful as indicators of food sources and trophic levels (Fry et al., 1999).

It is notable that juvenile $P$. callainos showed slightly lower $\delta^{13} \mathrm{C}$ and $\delta^{15} \mathrm{~N}$ in comparison to the largest females. Cichlid eggs have high lipid content (c. 3639\% dry mass in Oreochromis niloticus L.; Gunasekera et al., 1995) and lipid is usually depleted in both ${ }^{15} \mathrm{~N}$ and ${ }^{13} \mathrm{C}$ relative to associated proteinaceous tissue fractions (Kurle \& Worthy, 2002). Hence it is possible that isotopic signatures of juveniles are, to some extent, initiated through a maternal legacy obtained through the utilization of yolk within eggs, that is itself depleted in ${ }^{15} \mathrm{~N}$ and ${ }^{13} \mathrm{C}$. Maternal origin of the progeny's isotopic signatures has been noted in other fish species including smallmouth bass Micropterus domieu Lacèpede (Vander Zanden et al., 1998) and brown trout Salmo trutta L. (McCarthy \& Waldron, 2000). Indeed, the maternal legacy for brown trout can be so marked that it is possible 
to identify the offspring of anadromous and non-anadromous females on the basis of their isotopic signatures alone (McCarthy \& Waldron, 2000).

Stomach content analyses showed that the diets of juvenile $P$. callainos are dominated by phytoplankton. This is consistent with field observations of juveniles 'plucking' food items from the water within a few centimetres of the safety of their refugia (M.J. Genner, pers. obs.). It does not appear that juveniles actively embark upon foraging excursions. After this period in their life history, the results of this study revealed a switch to a diet comprised mainly of epilithic algae. It is not possible to be certain what factors contribute to this ontogenetic niche shift, but such shifts have been reported for many fish species. They are often associated with changes in morphology, behaviour and distribution, and are likely to be consequences of changes in selection pressures through the life cycle facilitated by changes in the balance between energy intake, reproductive success and the costs of competition, predation and parasitism. Diet changes can occur as individuals leave nursery grounds and enter new habitats with different available prey (Laegdsgaard \& Johnson, 2001). Dietary switches in some species such as pumpkinseed Lepomis gibbosus L., however, are thought to reduce inter- and intraspecific competition for shared resources, resulting in faster growth and higher individual fitness (Osenberg et al., 1992). Ontogenetic diet change has also been explained entirely on the basis of physiological demand. Smaller individual marblefish Aplodactylus punctatus (Valenciennes) have been found to have a high mass-specific protein demand that macroalgae cannot satisfy alone, hence juveniles must feed upon planktonic food items, but are able to switch at a later stage in the life cycle (Benavides, 1994). The dietary switch identified in P. callainos could be a combination of the change in habitat as leaving the refuge opens up more food items to exploitation; alternatively it may be a direct response to physiological requirements or a strategy to avoid competition and thereby increase individual fitness.

The isotopic signatures of the sexes were highly significantly different when size was not accounted for, but these differences were no longer significant when size was used as a covariate. This demonstrates the size-dependence of isotopic signatures in $P$. callainos after the ontogenetic shift, and indicates that the sex of individuals is not as important as size in determining the isotopic signatures of an individual. This was surprising, for irrespective of size differences between adult males and females, there are also large behavioural differences. Males are territorial all year round, defend space vigorously from many intruders and feed almost exclusively within their own territories (Genner et al., 1999). In contrast, females are not constrained by territoriality and are able to exploit transient food resources, such as plankton. This behavioural dichotomy may have contributed to the significant differences observed between the diets of adult males and females, with males exploiting more benthic food resources than females. It is possible that the sex-related dietary differences were also not found in corresponding isotopic signatures because they are not of a large enough scale, or perhaps these dietary differences are only apparent during brief periods of food shortage, leaving insufficient time for isotopic differences to arise.

It was unexpected to find such significant effects of body size on the isotopic signatures of adults and sub-adults. On the basis of available data it is not possible to identify the reasons for such change, but there are several possible 
explanations. The size-related patterns may be consequence of dietary changes that were not detected because sampling of individuals was conducted over an insufficient time period to encompass temporal dietary variation. Alternatively, observed size-related patterns could be due to changes in protein and lipid composition of the sampled tissue with increasing body size. Certainly isotopic signatures can vary with protein and lipid compositions of a given tissue (Peterson \& Fry, 1987; Pinnegar \& Polunin, 1999), that in turn are related to body condition (Doucett et al., 1999a). A third possible explanation is that sizerelated stable isotope accumulation is taking place that is independent of diet or lipid and protein compositional change. Such a phenomenon has been observed by Trask \& Van Dover (1999) who found size-related variability in $\delta^{15} \mathrm{~N}$ and $\delta^{13} \mathrm{C}$ of a sedentary filter feeding bivalve and Overman \& Parrish (2001) who report a size-related increase in $\delta^{15} \mathrm{~N}$ of $3.9 \%$ over the life history of walleye Stizostedion vitreum (Mitchill). At present it is not possible to distinguish between these competing, but non-mutually exclusive explanations for apparent linear isotopic change.

The changes in isotopic signatures of adults and sub-adults observed in this study demonstrate the dynamic nature of isotopic signatures during the life history of an organism. Thus, this work contributes to the growing body of literature indicating that an array of variables may be influencing the isotopic signatures of an organism (Harvey et al., 2002). The number of studies using isotopic analyses to infer trophic interactions and fine-scale ecological associations in aquatic environments is increasing. The present results, together with those of previous studies, clearly illustrate that future fine-scale analyses of stable isotope differentiation among taxa should consider intraspecific sizerelated variation and the timing life-history events, such as ontogenetic dietary switches.

This work would never have been possible without assistance from the Fisheries Department of the Government of Malawi, notably the staff at Nkhata Bay, especially G. Zgambo, H. Ngulube and M. Chiumia. S. Barker and J. Holah are thanked for assistance with stable isotope and stomach content analyses, respectively, and L. OdlingSmee and N. Chirwa are gratefully acknowledged for help in the field. Two referees greatly improved the manuscript with helpful suggestions. This work was funded by a small research grant awarded to MJG from the Fisheries Society of the British Isles. During the analysis and writing of this paper MJG was supported by European Commission Marie Curie Fellowship HPMF-CT-2000-798.

\section{References}

Beaudoin, C. P., Tonn, W. M., Prepas, E. E. \& Wassenaar, L. I. (1999). Individual specialisation and trophic adaptability of northern pike (Esox lucius): an isotope dietary analysis. Oecologia 120, 386-396.

Benavides, A. G. (1994). Ontogenetic changes in gut dimensions and macroalgal digestability in the marine herbivorous fish Aplodactylus punctatus. Functional Ecology 8 , $46-51$.

Bootsma, H. A., Hecky, R. E., Hesslein, R. H. \& Turner, G. F. (1996). Food partitioning among Lake Malawi nearshore fishes as revealed by stable isotope analysis. Ecology 77, 1286-1290.

Bray, J. R. \& Curtis, J. T. (1957). An ordination of the upland forest communities of southern Wisconsin. Ecological Monographs 27, 325-349. 
Clarke, K. R. \& Warwick, R. M. (1994). Change in Marine Communities: an Approach to Statistical Analysis and Interpretation. Plymouth: Plymouth Marine Laboratory.

DeNiro, M. J. \& Epstein, S. (1978). Influence of diet on the distribution of carbon isotopes in animals. Geochemica Cosmochimica Acta 42, 495-506.

Doucett, R. R., Booth, R. K., Power, G. \& McKinley, R. S. (1999a). Effects of the spawning migration on the nutritional status of anadromous Atlantic salmon (Salmo salar): insights from stable-isotope analysis. Canadian Journal of Fisheries and Aquatic Sciences 56, 2172-2180.

Doucett, R. R., Hooper, W. \& Power, G. (1999b). Identification of anadromous and nonanadromous adult brook trout their progeny in the Tabusintac river, New Brunswick, by means of multiple-stable-isotope analysis. Transactions of the American Fisheries Society 128, 278-288.

Fry, B. \& Arnold, C. (1982). Rapid ${ }^{13} \mathrm{C} /{ }^{12} \mathrm{C}$ turnover during growth of brown shrimp (Penaeus aztecus). Oecologia 54, 200-204.

Fry, B., Mumford, P. L., Tam, F., Fox, D. D., Warren, G. L., Havens, K. E. \& Steinman, A. D. (1999). Trophic position and individual feeding histories of fish from Lake Okeechobee, Florida. Canadian Journal of Fisheries and Aquatic Sciences 56, 590-600.

Genner, M. J., Turner, G. F. \& Hawkins, S. J. (1999). Resource control by territorial male cichlid fish in Lake Malawi. Journal of Animal Ecology 65, 522-529.

Griffin, M. P. A. \& Valiela, I. (2001). $\delta^{15} \mathrm{~N}$ isotope studies of life history and trophic position of Fundulus heteroclitus and Menidia menidia. Marine Ecology Progress Series 214, 299-305.

Gunasekera, R. M., Shim, K. F. \& Lam, T. J. (1995). Effects of dietary protein on puberty, oocyte growth and egg chemical composition in the tilapia, Oreochromis niloticus (L.). Aquaculture 134, 169-183.

Harvey, C. J. \& Kitchell, J. F. (2000). A stable isotope evaluation of the structure and spatial heterogeneity of Lake Superior food web. Canadian Journal of Fisheries and Aquatic Sciences 57, 1395-1403.

Harvey, C. J., Hanson, P. C., Essington, T. E., Brown, P. B. \& Kitchell, J. F. (2002). Using bioenergetic models to predict stable isotope ratios in fishes. Canadian Journal of Fisheries and Aquatic Sciences 59, 115-124.

Hobson, K. A. (1999). Tracing origins and migration of wildlife using stable isotopes: a review. Oecologia 120, 314-326.

Hobson, K. A. \& Clark, R. G. (1992). Assessing avian diets using stable isotopes I: turnover of ${ }^{13} \mathrm{C}$ in tissues. Condor 94, 181-188.

Hobson, K. A., Piatt, J. F. \& Pitocchelli, J. (1994). Using stable isotopes to determine seabird trophic relationships. Journal of Animal Ecology 63, 786-798.

Kelly, J. F. (2000). Stable isotopes of carbon and nitrogen in the study of avian and mammalian trophic ecology. Canadian Journal of Zoology 78, 1-27.

Kurle, C. M. \& Worthy, G. A. J. (2002). Stable nitrogen and carbon isotope rations in multiple tissues of the northern fur seal Callorhinus ursinus: implications for dietary and migratory reconstructions. Marine Ecology Progress Series 236, 289-300.

Laegdsgaard, P. \& Johnson, C. (2001). Why do juvenile fish utilise mangrove habitats? Journal of Experimental Marine Biology and Ecology 257, 229-253.

McCarthy, I. D. \& Waldron, S. (2000). Identifying migratory Salmo trutta using carbon and nitrogen stable isotope ratios. Rapid Communications in Mass Spectrometry 14, 1325-1331.

van Oppen, M. J. H., Turner, G. F., Rico, C., Deutsch, J. C., Ibrahim, K. M., Robinson, R. L. \& Hewitt, G. M. (1997). Unusually fine-scale genetic structuring found in rapidly speciating Malawi cichlid fishes. Proceedings of the Royal Society of London B 264, 1803-1812.

Osenberg, C. W., Mittelbach, G. G. \& Wainwright, P. C. (1992). Two-stage life histories in fish: the interaction between juvenile competition and adult performance. Ecology 73, 255-267. 
Overman, N. C. \& Parrish, D. L. (2001). Stable isotope composition of walleye: ${ }^{15} \mathrm{~N}$ accumulation with age and area-specific differences in $\delta^{13} \mathrm{C}$. Canadian Journal of Fisheries and Aquatic Sciences 58, 1253-1260.

Peterson, B. J. \& Fry, B. (1987). Stable isotopes in ecosystem studies. Annual Review of Ecology and Systematics 18, 293-320.

Pinnegar, J. K. \& Polunin, N. V. C. (1999). Differential fractionation of $\delta^{13} \mathrm{C}$ and $\delta^{15} \mathrm{~N}$ among fish tissues: implications for the study of trophic interactions. Functional Ecology 13, 225-231.

Preston, T. (1992). The measurement of stable isotope natural abundance variations. Plant Cell Environment 15, 1091-1097.

Ribbink, A. J., Marsh, B. J., Marsh, A. C., Ribbink, A. C. \& Sharp, B. J. (1983). A preliminary survey of the cichlid fishes of the rocky habitats of Lake Malawi. South African Journal of Zoology 18, 155-309.

Trask, J. L. \& Van Dover, C. L. (1999). Site specific and ontogenetic variations in nutrition of mussels (Bathymodiolus spp.) from the Lucky Strike hydrothermal vent field, Mid-Atlantic Ridge. Limnology Oceanography 44, 334-343.

Vander Zanden, M. J., Hulshof, M., Ridgway, M. S. \& Rasmussen, J. B. (1998). Application of stable isotope techniques to trophic studies of age-0 smallmouth bass. Transactions of the American Fisheries Society 127, 729-739.

Weyl, O., Kaiser, H. \& Hecht, T. (1996). On the efficacy and mode of action of 2-phenoxyethanol as an anaesthetic for goldfish, Carassius auratus (L.), at different temperatures and concentrations. Aquaculture Research 27, 757-764. 